\section{Telephones in Canada}

CANADA now probably takes the lead of every country in the world in the number of completed telephone calls a head, and considering the total number of telephones in use, it ranks fifth (Electrician, April 25). The total number of telephones in Canada showed an increase of about three per cent above 1939. In that year approximately 68 per cent of all instruments were residence telephones; 30 per cent were business and residence telephones on individual lines; while two-party lines accounted for 2 per cent. Nearly half of the telephones in operation in Canada in that year were on automatic switchboards, while during the year some 50,000 telephones were transferred from manual to automatic operation. In 1939, Canada had 12.35 telephones per 100 population as compared with 12.13 in 1938 . In 1938 Canada was surpassed only by the United States with $15^{\circ} 37$, Sweden with $12 \cdot 73$ and New Zealand $12 \cdot 69$ telephones per 100 population.

The number of telephones on automatic switchboards in Canada increased from 639,700 in 1938 to 690,201 in 1939, while the number of manual switchboards declined from 719,717 to 707,071 . The majority of the automatic telephones are located in fifty-one large cities. During 1939 telephones added or transferred from manual to automatic switchboards in these cities totalled 40,769 , as against 9,732 in other municipalities.

\section{Health of Glasgow}

IN his latest report Dr. A. S. M. Macgregor, the medical officer of health for Glasgow, states that the lower death-rates and the reduction in the incidence of common diseases in 1939 recall the experience of London and other cities in that year, but in 1940 Glasgow showed some disquieting features. The general death-rate during $1939--13 \cdot 3$ per $1,000-$ was the lowest on record. There were fewer deaths due to respiratory and infectious diseases. Infantile mortality fell to 80 per 1,000 births, the usual range being between 90 and 100. Deaths due to puerperal infection numbered 30 as compared with 50 the year before. During the first quarter of 1940, however, there was an outbreak of influenza, and by the end of January the death-rate had risen to $41 \cdot 1$ per 1,000 of the population. There was also an outbreak of paratyphoid fever with 274 cases but only 3 deaths. For the first time for many years measles was prevalent in the summer instead of in the winter. In the later part of 1940 diphtheria in Glasgow, as in some other parts of the country, reached its highest prevalence. Apart, however, from the influenza attack and the prevalence of diphtheria the health of Glasgow was almost as favourable in 1940 as in 1939 .

\section{Earthquake in Atlantic Ocean}

Tre United States Coast and Geodetic Survey, in co-operation with Science Service and the Jesuit Seismological Association, has determined the provisional epicentre of the earthquake of March 21,
1941, which took place at 7 h. $58 \cdot 4 \mathrm{~m}$. G.M.T. This they have found to be at latitude $7 \cdot 3^{\circ} \mathrm{N}$., longitude $38 \cdot 6^{\circ} \mathrm{W}$., which is in the Atlantic Ocean to the northeast of Brazil. The calculations were based on reports from the seismographic stations at Manila, San Juan, Fordham, Huancayo, Philadelphia and Logan, and it is suggested that although the depth of focus is to some extent uncertain, yet it may be of the order of $100 \mathrm{~km}$. Earthquakes in this region are somewhat rare though they are frequently experienced in certain parts of the West Indies ; but an earthquake of deep focus in this region is certainly a more rare occurrence, if not entirely without precedent.

\section{Johan August Hugo Gylden (r84I-I896)}

ON May 29 the centenary occurs of the birth of the eminent Swedish astronomer, Hugo Gylden, who for many years was director of the Stockholm Observatory. Gylden was the son of the professor of Greek at the University of Helsinki, and he received a careful training under his father. He also studied at Gotha and Leipzig, and at the former place came under the influence of Hansen. At the age of twenty. one he entered Pulkowa Observatory, and there, under Struve, began his investigations on the orbits of comets and planets. Nine years later he was called to Stockholm as director of the observatory and astronomer to the Royal Academy of Science, and he retained these appointments until his death on November 9, 1896. His papers exceeded two hundred in number, and related to the motion of planets and comets, the rotation of the earth, stellar parallax, refraction, mathematical analysis, cosmogony and other subjects. In 1879 he succeeded Secchi as a corresponding member of the Paris Academy of Sciences. He was made an associate of the Royal Astronomical Society, to which an obituary of him was contributed by his most famois pupil, Backlund.

\section{Announcements}

Sir ArthUR KeIth, lately Hunterian professor of the Royal College of Surgeons, has been elected a foreign associate member of the U.S. National Academy of Sciences.

Dr. PhIIIP R. White, of the Rockefeller Institute, Princeton, has been awarded the Stephen Hales Prize of the American Society of Plant Physiology for his work on plant tissue culture.

The Scientific Instrument Manufacturers Association of Great Britain, Ltd., of 60 Queen Victoria Street, London, E.C.4, has founded a scholarship in optics at the Imperial College of Science, South Kensington, up to $£ 40$ per annum, for a minimum of two years. The scholarship will be awarded immediately a suitable candidate presents himself.

ERratum. In the article "The Man of Science as Aristocrat" (NATURE, April 19, p. 465), for "the great lens" of the Lick Observatory read "the great mirror". 